\title{
EFFECT OFTHE RATION PROCESSING ONTHE APPARENT DIGESTIBILITY VALUES OF NUTRIENTS FOR THE PIAU (Leporinus elongatus)
}

\author{
Efeito do tipo de ração sobre a digestibilidade aparente dos \\ Nutrientes para Piau (Leporinus elongatus)
}

\author{
Priscila Vieira Rosa Logato ${ }^{1}$, Norka da Silva Albernaz $^{2}$, Paula Adriane Perez Ribeiro $^{3}$, \\ Rilke Tadeu Fonseca de Freitas ${ }^{1}$,Elias Tadeu Fialho ${ }^{4}$
}

\begin{abstract}
The experiment carried out at National Center for Research in Tropical Fish Pirassununga, SP, aiming to determine the effect of the ration processing on the apparent digestibility coefficients of the ingredients for the piau (L. elongatus). A total of 600 males of piau were utilized, allotted into six ponds of 300L. The applied treatments were: grinder processed ration, pelleting ration and extruded ration, utilizing rations with $32 \%$ crude protein and $3400 \mathrm{Kcal} \mathrm{DE} \cdot \mathrm{Kg}^{-1}$. The experiment was in a randomized blocks design with three treatments, three blocks and two replicates. The data were submitted to variance analysis by the SAEG computational package and the means of the treatments compared by SNK test (5\% of significance). The results showed that there were significant differences among the digestibility coefficients of both protein and energy for the pelleted and extrused rations $(\mathrm{P}<0.05)$. The results showed no statistical differences for the apparent digestibility coefficient of the dry matter $(\mathrm{P}>0.05)$.
\end{abstract}

Index terms: Feeding, fish, ingredients, nutrition.

\section{RESUMO}

O experimento foi realizado no Centro Nacional de Pesquisa de Peixes Tropicais de Pirassununga, SP, objetivando-se determinar o efeito do processamento da ração sobre os coeficientes de digestibilidade aparente dos ingredientes para o piau $(L$. elongatus). Foram utilizados 600 machos de piau, distribuídos em seis tanques de $300 \mathrm{~L}$. Os tratamentos aplicados foram: ração farelada, ração peletizada e ração extrusada, formuladas com 32\% de PB e $3400 \mathrm{Kcal} \mathrm{ED} / \mathrm{Kg}$. O delineamento experimental foi em blocos casualizados, com três tratamentos, três blocos e duas repetições por tratamento. As análises estatísticas foram realizadas pelo SAEG, com as médias comparadas pelo teste SNK (5\%). Houve diferenças entre os coeficientes de digestibilidade da proteína bruta e energia para as rações peletizada e extusada $(\mathrm{P}<0,05)$. A digestibilidade da matéria seca não diferiu mediante os processamentos avaliados $(\mathrm{P}>0,05)$

Termos para indexação: Alimentação, ingredientes, nutrição, peixe.

(Received in March 9, 2006 and approved in April 30, 2008)

\section{INTRODUCTION}

The aquaculture activity has developed gradually over the years. Therefore, the nutrition of fish comes from and focus on research, since spending on food represents about $60 \%$ of the final cost of production.

The research related to the formulation of balanced diets has made great technological advances in order to meet the growing demand. The proper balance of feed improves the utilization of nutrients by fish, minimizing costs and release of pollutants. The loss of nutrients in the water directly influences the development of animals, because it causes sharp increase in primary productivity of the culture tank, a loss in water quality (CARNEIRO et al., 1992).

The leaching of nutrients is more pronounced in the feed mash, depending on the relationship between the high surface area of contact and volume of water. Thus, the formulation of these diets typically require higher levels of water soluble ingredients, and the protective coating (oil), considering these possible losses.

The most employed in the manufacture of feed for aquaculture often combine temperature and pressure, giving thus increases the availability of nutrients, optimizing feed efficiency of fish. Thus, it combines better performance with less input of nutrients, which

\footnotetext{
'Zootecnistas, Doctors, Department of Animal Science / DZO - Federal University of Lavras / UFLA -Cx P. 3037 - $37200-000$ - Lavras, MG priscila@ufla.br; rilke@ufla.br

'Zootecnista, M.Sc. in Monogastric Nutrition - Department of Agricultural Sciences - Federal Education Technology Center of Cuiabá / CEFET - 78106000 - São Vicente da Serra, MT - norkasa@pop.com.br

${ }^{3}$ Zootecnista, PhD - Institute of Agricultural Sciences / ICA - University José do Rosário Vellano / UNIFENAS - MG 179, Km 0 - Cx P. 23 - $37130-000$ Alfenas, MG - paulaperezribeiro@hotmail.com

4Zootecnista, PhD, Department of Animal Science / DZO - Federal University of Lavras / UFLA - Cx P. 3037 - $37200-000$ - Lavras, MG - fialho@ufla.br
} 
compromises water quality. In Zamora \& Echevarria (1987), diets without prior processing, and which, therefore, raw starch, for example, are inadequate in the diet of fish, regardless of their feeding habits (carnivorous, herbivorous or omnivorous). The need for manipulation of starch, increasing its area of contact with the digestive enzymes is evident.

Thermal processes such as pelleting and extrusion provide, among other benefits, structural changes in carbohydrate, improving their use by animals. The process of pellet allows the mechanical compression ration within a chamber of pressing, with elevation of temperature of the mixture, giving greater consistency to it (KUBTIZA, 1998). The extrusion, in turn, combines high pressure and temperature, promoting the expansion of the starch molecules, improving, thus, its use by fish (FURUYA et al., 1998; HILTON et al., 1981; KUBTIZA, 1998).

Studies with Nile tilapia (Oreochromis niloticus L.) show that the extruded diets provide better feed for fish, with a consequent increase in weight gain when compared to pelleted feed and mash. However, its cost is higher, and the feasibility of their use should be examined (FURUYA et al., 1998). Work done by Ferreira (1995) and Smith et al. (1995) show also that the appropriate processing of the diets can not only improve the digestibility of starch, but also the availability of some minerals and digestibility of the protein, since its coefficient of digestibility varies largely depending on the temperature used in processing. Was conducted this study, to evaluate the use of different forms of feed processing on apparent digestibility coefficients of nutrients for piau (Leporinus elongatus Valenciennes, 1850).

\section{MATERIAL AND METHODS}

The experiment was conducted at the National Center for Research in Tropical Fish Pirassununga, SP (CEPTA / IBAMA), and 40 days of pre-trial for the adaptation of animals to different treatments. We used 600 males of piau (Leporinus elongatus) in the growth phase, housed in digestibility tanks with capacity of $300 \mathrm{~L}$. The treatments were:

1 - conventional mash diet;

2 - conventional pelleted diet;

3 - conventional extruded diet.

The diets were formulated with $32 \%$ crude protein and $3400 \mathrm{kcal} \mathrm{DE} / \mathrm{kg}$, using corn, soybean meal, fish meal, soybean oil, phosphoric acid, vitamin and mineral supplement. The percentage composition of the diet is presented in Table 1.
Table 1 - Percentage composition of experimental diet.

\begin{tabular}{lc}
\hline \multicolumn{1}{c}{ Ingredients } & Composition (\%) \\
\hline Corn & 34.96 \\
\hline Soybean meal & 45.97 \\
\hline Fish meal & 14.00 \\
\hline Phosphoric acid & 1.40 \\
\hline Soybean oil & 3.47 \\
\hline Supplement ${ }^{(1)}$ & 0.20 \\
\hline TOTAL & 100.00 \\
\hline Crude protein $(\%)$ & 32.00 \\
\hline Digestible energy $(\mathrm{kcal} / \mathrm{kg})$ & 3400.00 \\
\hline Crude fiber $(\%)$ & 3.65 \\
\hline Calcium $(\%)$ & 1.03 \\
\hline Phosphorus $(\%)$ & 0.98 \\
\hline
\end{tabular}

(1) Composition of vitamin and mineral supplement (amount per kilo of premix): VitA, 1500UI; VitB , 20mg; VitB, 15mg; VitB, $1000 \mathrm{U}$; VitB ${ }_{12}$, 10mcg; VitE, 25mg.; VitPP, 120mg; Hill, 2000mg; Pantotenic acid, 80mg; Folic acid, 2mg, Mn, 80mg; Fe, 24mg; Zn, 50mg; Cu, 8mg; I 3mg; If, 0.10 mg, BHT, 170 mg.

The animals received the diet "ad libitum", three times daily (8:00, 12:00 and 17:00 hours). After 30 minutes of the last feeding, the digestibility tanks were siphoned for the removal of waste from food and faeces out of the traps and clean. The standard limnological parameters in digestibility tanks were monitored daily, to control water temperature and dissolved oxygen content for digital portable oximeter, the $\mathrm{pH}$ using a $\mathrm{pH}$ meter $\mathrm{CG} 711$, and the levels of ammonia , using a commercial kit Labcon Test ${ }^{\circledR}$, with the values obtained by comparison of patterns colorimetric scale.

The experimental design was randomized blocks with three treatments (processing of feed), three blocks (experimental periods) and two replications per treatment per period of collection. The statistical model used was:

$$
y_{i j k}=\mu+t_{i}+b_{j}+e_{i j k}
$$

where:

$\mathrm{y}_{\mathrm{i} j \mathrm{k}}=$ sampling plot on the diet $\mathrm{i}$, in the block $\mathrm{j}$ and replicate $\mathrm{k},(\mathrm{i}=1,2,3), \mathrm{j}=(1,2,3)$ and $\mathrm{k}=(1.2)$;

$\mu=$ mean yield of the experiment;

$\mathrm{t}_{\mathrm{i}}=$ effect of diet $\mathrm{i}(\mathrm{i}=1,2,3)$;

$b_{j}=$ effect of period $j(j=1,2,3)$;

$e_{i j k}=$ deviation associated with each observation that, by definition, has a normal distribution with zero mean and variance $\mathrm{d}^{2}$. 
Statistical analysis was performed using the program SAEG (System for Genetic Analysis and Statistics), proposed by Euclydes (1997), and the averages of the treatments compared by Student Newman Keuls test (SNK), the $5 \%$ significance.

The collection of faeces for laboratory testing was performed daily, at 8 , while an interval of 24 hours between collections. The digestibility of experimental diets was determined by indirect method, where the ingestion of food and collection of excreta were partial, using as the inert marker chromium-III oxide $\left(\mathrm{Cr}_{2} \mathrm{O}_{3}\right)$ in the proportion of $1 \%$. The feces collected were centrifuged at 5000rpm for eight minutes, weighed, pre-dried in ventilated oven at $60^{\circ} \mathrm{C}$ for 24 hours and frozen at $-10^{\circ} \mathrm{C}$ for later analysis of dry matter, crude protein, energy Gross and chromium-III oxide (AOAC, 1998).

The calculation of the digestibility of nutrients was carried out according to the equation proposed by Maynard et al. (1984) and Nose (1966):

Digestibility $(\%)=100-\left[\left(\% \mathrm{Cr}_{2} \mathrm{O}_{3}\right.\right.$ feed $/\left(\% \mathrm{Cr}_{2} \mathrm{O}_{3}\right.$ feces $) \mathrm{x}$ ( $\%$ nutrient faeces $/ \%$ nutrient diet) $] \times 100$

\section{RESULTSAND DISCUSSION}

The limnological parameters have remained within the normal ranges for the creation of piau (Leporinus elongatus), and mean values of $\mathrm{pH}$, ammonia, dissolved oxygen and temperature of $6.5,0.16 \mathrm{mg} / \mathrm{L}, 5.62 \mathrm{mg} / \mathrm{L}$ and $25.08^{\circ} \mathrm{C}$, respectively.

The values of apparent digestibility of diets, subjected to different processes, on digestibility coefficients of dry matter (DCDM), crude protein (DCCP) and gross energy (DCGE) are presented in Table 2.

Table 2 - Coefficients of apparent digestibility of piau (Leporinus elongatus), depending on the ration provided.

\begin{tabular}{lccc}
\hline \multirow{2}{*}{ Treatment } & \multicolumn{3}{c}{ Parameters $^{1}$} \\
\cline { 2 - 4 } & DCDM (\%) & DCCP (\%) & DCGE (\%) \\
\hline Mash diet & $95.42 \pm 0.38 \mathrm{a}$ & $64.56 \pm 2.30 \mathrm{~b}$ & $81.94 \pm 0.76 \mathrm{~b}$ \\
Pelleted diet & $93.20 \pm 0.29 \mathrm{a}$ & $71.20 \pm 1.57 \mathrm{a}$ & $86.43 \pm 0.36 \mathrm{a}$ \\
Extruded diet & $93.64 \pm 1.42 \mathrm{a}$ & $72.48 \pm 1.10 \mathrm{a}$ & $85.85 \pm 0.21 \mathrm{a}$ \\
\hline
\end{tabular}

${ }^{1}$ Médias followed by same letter in column do not differ among them by SNK test $(\mathrm{P}>0.05)$.

DCDM - digestibility coefficient of dry matter; DCCP digestibility coefficient of crude protein; DCGE - digestibility coefficient of gross energy.

The values of digestible dry matter to feed mash, pellets and extruded, obtained in this work, did not differ significantly between them $(\mathrm{P}>0.05)$. KIRCHGESSNER et al. (1986) studied the digestibility of nutrients for common carp (Cyprinus carpio L.), reported similar values, while Oliva-Teles et al. (1994) have found lower levels for that parameter, to work with different forms of processing of feed for rainbow trout (Oncorhynchus mykiss Walbaum, 1792), obtaining an average of $77.2 \%$.

The treatments evaluated in this study showed differences in digestibility coefficients of crude protein and gross energy, and the pelleted and extruded diets showed higher levels on the processed feed mill $(\mathrm{P}<0.05)$. The digestibility of protein was lower than that presented by Fernandes et al. (1998) for soybean meal, which found an average of $79.20 \%$ for pacu (Piaractus mesopotamicus Holmberg, 1887). The coefficients of digestibility of energy, the diets evaluated in this study, were similar to those reported by Oliva-Teles et al. (1994), which, working with trout, had averages of $86.80 \%$ and $88.90 \%$ respectively.

The digestibility of nutrients may vary, among other factors, depending on the processing of the diet, especially in relation to the temperature used in the technique. Thus, an inappropriate processing means, often in a lower digestibility of nutrients.

By studying the apparent digestibility coefficients of dry matter, gross energy and crude protein of soybean meal and corn, among other ingredients for Nile tilapia (Oreochromis niloticus), Thai lineage, Boscolo et al. (2002) observed apparent digestibility coefficients of dry matter to $65.49 \%, 89.58 \%$ for crude protein and $71.38 \%$ for gross energy, for the soybean meal, and $73.22 \%$ for area; $93,40 \%$ for crude protein and $76.63 \%$ for gross energy, for the corn, noting that this species uses energy efficiently and protein of these ingredients.

In further studies with Nile tilapia (Oreochromis niloticus), Pezzato et al. (2002), evaluating the digestibility of food energy and protein, found between the food energy that the corn had the highest apparent digestibility coefficients (dry matter: $52.52 \%$ and crude protein: $91.66 \%$ ) and among protein foods, the soybean meal was also ranked best, with coefficients of digestibility of dry matter of $71.04 \%$ and crude protein of $91.56 \%$.

An important factor to be considered is the effect of the interaction between temperature and the production process used in the manufacture of the diets. According Ciacci \& Cruz (1992), the heating of an aqueous suspension of starch causes the gelatinization, leading to breakage of hydrogen bridge links by encouraging and thus the leaching of amylase from granules. This promotes an increase in the solubilization of starch. The range of temperature for this event is between $62^{\circ} \mathrm{C}$ and $72^{\circ} \mathrm{C}$. The efficiency of utilization of starch by animals, represented by the enzymatic hydrolysis of digestive processes, 
depends directly on the degree of starch gelatinization that.

During the thermal processing employed in this study, the temperature of the starch of corn gelatinization, used in the formulation of the diets was maintained around $52^{\circ} \mathrm{C}$ to pellet and $42^{\circ} \mathrm{C}$ in the extrusion, verified by a Brabender viscoamylograph, keeping is thus within the range recommended.

According to Ferreira (1995), the appropriate processing can improve the digestibility of starch and protein, and the availability of minerals. Values of protein and digestible energy of extruded and pelleted diets are associated with the instability of the extruder, due to problems of compaction of the mixture, imbalance of flux, humidity and adjust the temperature and pressure (COELHO, 1997). This fact was confirmed by ANDRIGUETTO (1990), to note that variations in the values of the nutrient digestibility of animal by-products were related to the variety of raw material used and its process of production.

However, it is important to emphasize that the diet and processed, by extrusion or pelletization, remains stable in water for longer when compared to non-processed diet, avoiding excessive losses and discharge of effluents.

\section{CONCLUSIONS}

The process of extrusion and pelleting were responsible for the higher coefficient of digestibility of protein and energy, showing that the degree of heat treatment improves the availability of nutrients and utilization of feed for animals.

\section{REFERENCES}

ANDRIGUETTO, P.; MINAR, G.; FLEMING, S.; BONA, F. Nutrição animal. 4. ed. São Paulo: Nobel, 1990. 395 p.

\section{ASSOCIATION OF OFFICIAL AGRICULTURE CHEMISTRY. Official methods of analysis of the Association of Official Agriculture Chemistry. Washington, DC, 1998. 1102 p.}

BOSCOLO, W. R.; HAYASHI, C.; MEURER, F. Digestibilidade aparente da energia e nutrientes de alimentos convencionais e alternativos para a tilápia do Nilo (Oreochromis niloticus, L). Revista Brasileira de Zootecnia, Viçosa, v. 31, n. 2, p. 1585-1591, 2002.

CARNEIRO, D. J.; CHAIN, S. H. S.; DIAS, T. C. R. Efeito do processamento das dietas comerciais sobre o desenvolvimento produtivo do pacu Piaractus mesopotamicus (Holmberg, 1887). In: ENCONTRO NACIONAL DE AQUICULTURA, 2., 1992, Peruíbe, SP. Resumos... Peruíbe, SP: Associação Brasileira de Aqüicultura, 1992. p. 44-51.

CIACCO, F. C.; CRUZ, R. Fabricação de amido e sua utilização. São Paulo: Fundação Tropical de Pesquisa e Tecnologia, 1992. 151 p. (Série tecnologia agroindustrial).

COELHO, S. R. C. Situação atual e perspectivas da indústria de rações para organismos aquáticos. In: SIMPÓSIO SOBRE MANEJO E NUTRIÇÃO DE PEIXES, 1997, Piracicaba, SP. Anais... Campinas: CBNA, 1997. p. 102-116.

\section{EUCLYDES, R. F. Manual de utilização do programa SAEG (Sistema para Análises Estatísticas e Genéticas).} 2. ed. Viçosa: UFV, 1997. 150 p.

FERNADES, J. B. K.; CARNEIRO, D. J.; SAKOMURA, N. R.; VIEGAS, E. M. M. Fontes e níveis de proteína bruta para alevinos e juvenis de pacu (Piaractus mesopotamicus). In: AQUAICULTURA BRASIL 98, 1998, Recife, PE. Resumos... Recife: Associação Brasileira de Aqüicultura, 1998. p. 10.

FERREIRA, E. R. A. Composição química e valores de digestibilidade da proteína e energia de alguns alimentos para suíno. 1995. 50 f. Dissertação (Mestrado em Nutrição de Monogástricos) - Universidade Federal de Lavras, Lavras, 1995.

FURUYA, W. M.; SOARES, S.; FURUYA, V. R. B.; HAYASHI, C.; RIBEIRO, R. P. Dietas peletizadas e extrusadas para tilápia do Nilo (Oreochromis niloticus), no período de terminação. Ciência Rural, Santa Maria, v. 28, n. 3, 1998.

HILTON, J. W.; CHO, C. Y.; SLINGER, S. J. Effect of extrusion processing and steam pelleting diets on pellet durability, pellet water absorption, and the physiological response of rainbow trout (Salmo gairdneri R.). Aquaculture, Amsterdam, v. 25, p. 185-194, 1981.

KIRCHGESSNER, M.; KÜRZINGER, H.; SCHWARZ, F. J. Digestibility of crude nutrients in different feeds and estimation of their energy content for carp (Cyprinus carpio L.). Aquaculture, Amsterdam, v. 58, p. 185-194, 1986. 
KUBITZA, F. Qualidade da água na produção de peixes. Campo Grande: [s.n.], 1998. 60 p. Apostila.

MAYNARD, L. A.; LOOSLI, J. K.; HINTZ, H. F.;

WARNER, R. G. Nutrição animal. 3. ed. Rio de Janeiro: F. Bastos, 1984. 726 p.

NOSE, T. Protein digestibility of Brown fish meal in rainbow trout. Bulletin of the Fresh Fisheries Research Laboratory, Tokyo, v. 15, n. 2, p. 213-224, 1966.

OLIVA-TELES, A.; GOUVEIA, A. J.; GOMES, E.; REMA, $P$. The effect of different processing treatments on soybean meal utilization by rainbow trout, Oncorhynchus mykiss. Aquaculture, Amsterdam, v. 124, p. 343-349, 1994.
PEZZATO, L. E.; MIRANDA, E. C.; BARROS, M. M.; PINTO, L. G. Q.; FURUYA, W. M.; PEZZATO, A. C. Digestibilidade aparente de ingredientes pela tilápia do nilo (Oreochromis niloticus). Revista Brasileira de Zootecnia, Viçosa, v. 31, n. 4, p. 1595-1604, 2002.

SMITH, R. R.; WINFREE, R. A.; RUMSEY, G. W.; ALLRED, A.; PETERSON, M. Apparent digestion coefficients and metabolizable energy of feed ingredients for rainbow trout, Oncorhynchus mykiss. Journal of the World Aquaculture Society, Bethesda, v. 102, n. 4, p. 432-437, 1995.

ZAMORA, S.; ECHEVARRIA, G. Los hidratos de carbono en la nutrición de los peces. In:

Nutricion en aquicultura. 2. ed. Madrid: Comisión Asesora de Investigación 